\title{
Extreme Empiricism: John Howard, Poetry, and the Thermometrics of Reform
}

\author{
Gabriel Cervantes \\ University of North Texas \\ Dahlia Porter \\ University of North Texas
}

\begin{abstract}
I labour to convey the torch of philanthropy into these distant regions.-I am quite well—the weather clear-the mornings fresh-thermometer 48 , but fires not yet begun. I wish for a mild winter, and then shall make some progress in my European expedition. My medical acquaintance give me but little hope of escaping the plague in Turkey. I do not look back, but would readily endure any hardships, and encounter any dangers, to be an honour to my Christian profession.
\end{abstract}

-John Howard to Richard Price, Moscow, 22 September $1789^{1}$

—And now, BENEVOLENCE! Thy rays divine

Dart round the globe from Zembla to the Line; ...

From realm to realm, with cross or crescent crown'd,

Where'ere Mankind and Misery are found,

O'er burning sands, deep waves, or wilds of snow,

Thy HOWARD journeying seeks the house of woe.

—Erasmus Darwin, Loves of the Plants (1789)2

In a letter to Richard Price, the famed prison reformer John Howard (1726-90) raises a cluster of issues that preoccupied him for much of his life: philanthropy, travel, temperature, medicine, and Christian duty. Howard figures himself as a martyr, a man destined to die (as he did only four months later) on the holy mission of bringing the light of philanthropy to a plague-ridden East. At the same time, Howard portrays himself engaged in the Enlightenment project of empirical observation: he carefully notes climatic changes and temperatures, a habit developed while traveling from prison to prison across Europe collecting the data that would underwrite his arguments for prison reform. To this 
unsettling conjunction of the proselytic and the empirical, Howard adds a bid for authority: he distinguishes himself from his "medical acquaintance" while claiming a professional status based on the rigorous pursuit of duty rather than institutional sanction. Not a member of any of the three liberal professionsmedical, legal, or clerical-Howard amalgamates diverse methods and fields of eighteenth-century knowledge production, shifting comfortably from faith to fact, torch to thermometer in the space of a few sentences. At a moment when older professional categories were giving way to modern disciplinary configurations, Howard stands at a crossroad.

Howard's letter to Price emblematizes the messy pre-disciplinarity characteristic of late eighteenth-century Britain. ${ }^{3}$ His blend of Christian philanthropy and empirical observation is not unique: it has a history stretching back to seventeenth-century physico-theology, and retained currency through the eighteenth century despite the rise of philosophical materialism. ${ }^{4}$ Howard is nonetheless remarkable because-like Isaac Newton-he became a powerful cultural icon. In the 1780s and 1790s his concern with temperature, data compilation, and Christian benevolence supplied other authors with a figurative system that fused models of knowledge production to social and political movements of the era. After the initial publication of The State of the Prisons in 1777, Howard's activities and character became the locus of wide-ranging debates about the relationship between not only philanthropy and reform, but also between empiricist methods, climate science, colonialism, and medical practice. Our epigraph from poet and physician Erasmus Darwin shows how: these lines imagine Howard as an angel of philanthropy spreading divine rays of benevolence across political and religious boundaries. Expanding the geographic breadth of Howard's travels, Darwin extends the reach of British reform movements from Zembla (an island in the Arctic Ocean) to the equator, traversing the thermometric scale from extreme cold to extreme heat. While metaphors of heat and cold long predate the development of thermometric science and its application to prison reform, eighteenth-century debates over standardizing thermometers and a massive accumulation of thermometric data revalued this metaphoric system, enabling Darwin's poetic transmutation of the reformer into an atmospheric agent with a global reach. As this essay shows, Howard and his literary panegyrists persistently link temperateness to Christian charity and cast both as valuable British exports to climatically challenging geographies. Howard, poets argued, had ushered in Britain's newly benevolent empire.

Howard proved a powerful icon for several reasons: his attention to the oppressed in society, particularly incarcerated debtors whose punishment appeared too harsh for their crimes; his technique of compiling masses of empirical evidence, presented in detailed charts and tables, to support his claims; his focus on alleviating distress by curing illnesses, physical and moral; and his unremitting dedication to-and self-sacrifice for-a humanitarian cause. ${ }^{5}$ 
During his life, Howard attained a measure of real power in medical and legal circles: he co-authored the 1779 Penitentiary Act with William Blackstone and published medical recommendations for improving prisoners' health in direct opposition to those of the Royal College of Physicians. After his apparently self-inflicted death in 1790, however, even Howard's staunchest defenders grasped that his empiricist project-defined by an obsessive, single-minded pursuit of facts-had taken on the aspect of over-heated enthusiasm. As an established advocate for sanitary reform based on empirical observation, what made Howard iconic-and eminently useful for poets' visions of reforming Britain's global empire-also made him an anathema to physicians attempting to reform the practice of medicine and consolidate its standing as a scientific discipline. This tension, we argue, pitted poets' mobilizations of Howard against the strictures of professionalism. As we show in the final section of the essay, the dissenting physician John Aikin-Howard's close friend, literary executor, and posthumous biographer-defended the reformer against charges of enthusiasm while also dissecting his medical knowledge and presenting him as a case study in the dangers of self-diagnosis. Aikin's judgment illustrates how medicine's claims to professional legitimacy necessitated the expulsion of religious fervor, the defining characteristic of Howard's "Christian profession" of empiricist philanthropy and the trait that galvanized contemporary reform literature.

In focusing on Howard this essay seeks to bridge recent scholarship on reform culture, colonialism, and discipline formation in late eighteenth-century Britain, and to demonstrate the mutually productive relationship between these endeavors. But this essay is also a project of literary recovery. Where historical accounts have attempted to explain Howard's rise to prominence, they have ignored the quantity and quality of published poetry about Howard and his prison reform agenda. ${ }^{6}$ Our epigraph from Darwin's long poem is part of an expansive and virtually unexplored archive of poetry and periodical writing. Panegyric and elegiac poems about Howard became nearly ubiquitous in the 1780s and 1790s: snatches of verse on Howard appeared in long poems like Darwin's Loves and William Cowper's "Charity," and an astonishing number of free-standing odes, sonnets, inscriptions, epistles, epigrams, lines, and monodies on Howard were printed, reprinted, and imitated in periodicals and excerpted in contemporary educational anthologies like Vicesimus Knox's Elegant Extracts of Poetry (1791). Howard became a theatrical hero in Elizabeth Inchbald's successful play, Such Things Are (1788), and a spate of eulogies and biographical notices filled the papers after Howard's death in the Ukraine in 1790.

This literary and popular outpouring formed the core of a sustained cultural engagement with prison reform that cut across genres, media, and social divisions structured by political party and religious affiliation. Indeed, one can trace the familiar tropes of Romantic-era prison literature by William Godwin, Wil- 
liam Wordsworth, Samuel Taylor Coleridge, and Mary Hays to earlier poems about Howard by William Hayley, Cowper, Robert Merry, Samuel Jackson Pratt, and William Lisle Bowles. This earlier verse-commonly written off as a litany of dreadful couplets dripping with inflated, banal sentimentalism-developed aesthetic strategies for representing the confluence of empirical methods of data collection and a multifaceted, far-reaching Christian charity. These strategies would be taken up to support other reform causes, most famously abolition, in the following decades. Accounting for the cultural currency and lasting influence of verse about Howard reveals literature's relationship to other fields of knowledge production at an early moment in the consolidation of disciplines and, just as importantly, portentous shifts in the cultural authority of scientific, literary, and religious knowledge.

\section{THE TEMPERATURE OF SUFFERING}

John Howard was a gentleman of independent means. The son of a wealthy London upholsterer, he was educated at John Eames's dissenting academy in London, inherited his father's fortune at age 16, and took the requisite grand tour of Europe in 1748 at age 22. Finally settling in Cardington, Howard was appointed High Sheriff of Bedfordshire in 1773, a position that spurred him to begin an inspection of local prisons. As he indicates in the opening pages of The State of the Prisons, he began to visit jails "to gain a more perfect knowledge of the particulars and extent of [the distress of prisoners], by various and accurate observation," and he continued visiting prisons across Britain and Europe, meticulously recording conditions, until his death. ${ }^{7}$ Pursuing a seemingly haphazard course, Howard conducted 1,441 individually dated visits to 224 different prisons in England and Wales, along with hundreds of visits to foreign prisons; fearing deceit, he visited most of these prisons multiple times. ${ }^{8}$ By 1777, he had enough data to publish in book form. As Aikin details in his posthumous biography, Howard's observations were initially collected in "detached and broken memorandums"; this data was subsequently collated, arranged, and "put into correct language" — primarily by Richard Price and Aikin — to form the continually expanding editions of The State of the Prisons. ${ }^{9}$ In its printed form, the short narrative sections-describing "Distress in Prisons" and the customs that produce it-are supported by upwards of 400 pages of detailed descriptions and numerical tables. This immense databank led Victorian physician William Guy to proclaim Howard "one of the foremost statists of his time."10

Contemporaries recognized that Howard's procedures of collecting and presenting data were fundamental to his reformist agenda. For example, in a 1780 speech Edmund Burke contrasts Howard with a gentleman aesthete on the grand tour, arguing that Howard traveled not for pleasure but "to survey the mansions of sorrow and pain; to take the gage and dimensions of misery, depression, and contempt; ... and to compare and collate the distress of all men 
in all countries."11 Burke enumerates Howard's methods ("survey," "gage," "compare," "collate") while translating them into the moral register that defined Howard's peculiar "circumnavigation of charity" in the popular imagination. ${ }^{12}$ Unlike early eighteenth-century prison reformers Moses Pitt, Thomas Bray, and James Oglethorpe-whose committee reports and essays aimed primarily at censuring individual corrupt jailers for arbitrary decisions and ethical trespasses-Howard aimed to systematically record the physical conditions in prisons that impinged on inmates' health and wellbeing. ${ }^{13}$ An emblematic instance of what Mary Poovey calls the "modern fact," the tabular presentation of numerical data in The State of the Prisons indicted the prison system as a whole, proving the pressing need for comprehensive reform. ${ }^{14}$ The strategy worked: while earlier attempts had failed to provoke legislation, Howard's survey of deleterious conditions yielded the 1774 Parliamentary "Act for Preserving the Health of Prisoners," a law still recognized as foundational in modern prison theory.

While impressive in its scope and comprehensiveness, Howard's tabular presentation of data was by no means unique in the period. Quantification was a hallmark of eighteenth-century natural and social science; everyone-from Samuel Johnson to a host of less famous weather observers-was obsessed with taking measurements. This cultural preoccupation had conceptual roots in Francis Bacon's inductive method with its focus on observation and experiment, the guiding force behind the Royal Society's program of data collection and measurement in the seventeenth century. ${ }^{15}$ By the mid-eighteenth century, however, a turn toward specifically numerical data had engendered new fields of inquiry, including political and medical arithmetic. ${ }^{16}$ Howard's closest collaborators, Price and Aikin, were avid participants in these developments. In his work for the Society for Equitable Assurances, Price collected demographic data on life expectancy and population growth; the result of this work, Observations on Reversionary Payments (1771), concludes with a chapter on the "proper Method of constructing tables for determining the Rate of human Mortality" followed by an appendix of algebraic demonstrations and tables for computing compound interest. ${ }^{17}$ Aikin advocated for the experimental practice of medicine in his Thoughts on Hospitals (1771), and supported his case with a letter from the physician Thomas Percival, an advocate for empirical medicine who recommended keeping detailed registers of deaths and diseases. Howard's survey of prison conditions and the way he presented his findings, including both demographic and health data, were clearly informed by the work of his collaborators.

But Howard's interest in measurement had a particular bent, one established long before he began quantifying prisoner distress. Following the Royal Society's practice of attaching gentlemen of independent means to their cause, Howard was inducted as a Fellow in 1756. Over the next fifteen years, he followed the Society's mandate that each member "contribute something to the common stock of knowledge" by publishing three short papers in the Philo- 
sophical Transactions: "On the degree of Cold Observed at Cardington in the Winter of 1763," "On the Heat of the Waters at Bath" in 1767, and "On the Heat of the Ground on Mount Vesuvius" in $1771 .{ }^{18}$ These efforts reveal an investment in temperature that goes beyond passing curiosity: as Aikin relates, while at home Howard would "leave bed at two every morning, for the purpose of observing the thermometer, which was placed in his garden, some distance from his house," and Howard's correspondence indicates he was still sending thermometer readings to acquaintances in February 1789. ${ }^{19}$ Jan Golinski's detailed analysis of weather diarists indicates that gentlemen across Britain shared this interest in methodically recording atmospheric conditions. Howard merely turned this practice to practical ends by making temperature a central component in his arguments for prison reform.

Howard was in the habit of taking thermometer readings in the prisons he visited, but (for reasons we discuss below) this information was not presented in numerical tables in The State of the Prisons. Instead, Howard uses thermometric language to provide a framework in which demographic and economic data becomes evidence for the necessity of reform. References to temperature are woven into narrative sections and footnotes, specifically in conjunction with recommendations for improving prisoner health through diet, cleanliness, and air circulation. The State of the Prisons (in particular the expanded third edition of 1784) recommends warm baths for the sick, warm soup, and airy, ventilated rooms while condemning dungeons like the Bastille that were excessively hot in summer and very cold in winter. ${ }^{20}$ When hundreds of prisoners perished in a Pentworth jail in 1775, Howard blames temperature: "I do not affirm these men were famished to death; it was extreme cold." ${ }^{21}$ In another instance, the severe cold that caused several hundreds to perish signaled other failures inside a prison: the rooms were dirty and lacked fireplaces, and the prisoners were the sickly and melancholy. ${ }^{22}$ The State of the Prisons is particularly critical of prisons in hot climates that blocked the "free admission" of fresh, cooling air, and his proposed improvements center on constructing and managing prisons so as to ensure adequate air circulation. ${ }^{23}$ As these examples show, Howard's criticisms of jails and recommendations for their improvement were underwritten by pitting the extremes of hot and cold against temperateness produced by good ventilation. While his charts and tables relayed numbers of prisoners, fees, salaries, and prisoner allowances, the standard used to evaluate prisoner distress was thermometric and atmospheric: bad prisons were low, damp, close, overheated, offensive and noisome; good prisons were mild, airy, clean, and wholesome. Temperature functions as an argumentative framework, but it also provides a universally applicable standard that allowed the wealth of numerical data to serve as the evidentiary base for reform.

While earlier prison reformers had recognized that temperature affected prisoners' health, Howard's recourse to a thermometric standard registers a larger epistemological shift in medical discourse toward verification and 
standardization. Howard's particular approach-juxtaposing extremes to temperateness - reflects a specific methodological problem: in order to determine how temperature impinged on human health, it was necessary to collect comparable thermometric data, which in turn depended on the instruments used to take readings. As early as 1693, Edmund Halley complained that instruments were never "graduated, but by standards kept by each particular workman, without any agreement or reference to one another." ${ }^{24}$ This problem persisted into the eighteenth century, as evidenced by Howard's care in distinguishing readings given on Reaumur's scale and those obtained with Fahrenheit's thermometer. ${ }^{25}$ The problem of non-standardized instruments likely accounts for the absence of tables of temperature readings in Howard's book. By the mid-eighteenth century, it had become clear that observations would only be meaningful when measured against a standard scale of fixed points, but competing models proposed scales based on everything from the congealing oil of aniseed to the temperature in the Paris Observatory cellars. Early "two-point" systems, by contrast, proposed "most severe winter cold and greatest summer heat" or "snow and highest summer heat" as the fixed points of the scale. ${ }^{26}$ This shift to climatic extremes as fixed points corresponded with a growing body of data: early in the century, the Philosophical Transactions began publishing papers on degrees of cold or heat, and-like Howard's contributions on winter cold, hot springs, and volcanic ground-these entries most often record extreme conditions. ${ }^{27}$ By mid-century, instrument makers followed this trend. In 1761, for example, another Fellow of the Royal Society, Keane Fitzgerald, proposed a new thermometer to "mark the common degrees of heat and cold of this climate" 28 (see Fig. 1). The instrument's clock face records "extreme" heat and cold in the same bottom-most position, diametrically opposite "temperate" weather at the top mark bounded by moderate warm and cold on either side. Inserting prisoners into a scale between climatic extremes turns data into a problem of inhumane treatment: the physical and moral health of any jail can be registered and documented by its deviation from temperateness.

As Fitzgerald's design suggests, Howard's search for a standard measurement of prisoner distress takes place within larger debates over the effect of climate and geography on human bodies. In the seventeenth and eighteenth centuries, it was commonly held that climatic changes had a direct effect on health, and new instruments like the thermometer and barometer were understood to register "atmospheric conditions that impinged upon the body at the level below conscious awareness." 29 This conjunction of climate and health was, as Alan Bewell has argued, inseparable from the invention of medical geography. British medical and literary writers comprehended their own bio-medical identity within the global context of colonialism, specifically in relationship to the pathologized tropics whose climate was "sick" and needed to be cured. ${ }^{30}$ As the common designation "torrid zone" indicates, medical geographers set climatic extremes against temperateness, which allowed them to argue that 


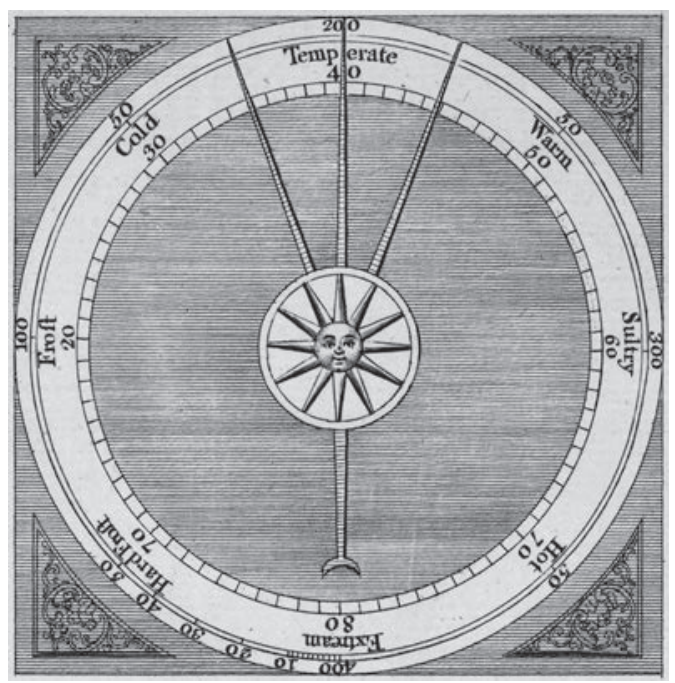

Fig. 1: Design for a thermometer with registers by Keane Fitzgerald, Philosophical Transactions 52 (London, 1761-62). Courtesy of the Huntington Library, San Marino, California.

Britain's climate was, on the whole, conducive to health. ${ }^{31}$ However, because the most common afflictions, fevers, were thought to arise from miasma or bad air, spaces within temperate climates-like overcrowded hospitals or jailsmight become diseased by having a concentration of noxious vapors. Medical publications reinforced this conjunction: James Lind, famous for his treatment of scurvy, grounded his influential Essay on the Diseases incidental to Europeans in Hot Climates (1768) on the results of his earlier empirical observations of fevers in hospitals and jails in Britain. ${ }^{32}$ Howard's thermometric and atmospheric standard for judging the relative health of prisons was thus bound up with the medicalization of climate, and particularly the relationship between diseased colonial environments and diseased spaces within Britain itself. It is this conjunction, we will argue below, that galvanized prison reform poetry of the late eighteenth century and made Howard into a powerful cultural icon for Britain's newly benevolent empire.

\section{THE POETICS OF CLIMATE CONTROL}

For Howard, the link between temperature and suffering was a literal one, and The State of the Prisons rarely steps away from reportage into appeals to sentiment. Even in his introductory statements on distress in prisons, Howard repeatedly emphasizes his aim of "set[ting] down matter of fact without amplification" and that his "collections are not published for general amusement" but 
to promote legal redress. ${ }^{33}$ Given this penchant for accuracy, Howard conveys scenes of distress with muted sensibility. Reform poetry written about Howard in the 1780s and 1790s, by contrast, trades heavily in tropes of heightened emotion. A foundational example of this transmutation of "matters of fact" into sentimental effusion can be seen in the frontispiece for William Hayley's Ode Inscribed to John Howard (1780), the seminal poetic treatment of Howard that introduced tropes current in reform verse across the last two decades of the eighteenth century. The engraving by Francesco Bartolozzi (see Fig. 2), based on a drawing by George Romney, illuminates a very small detail added to the second edition of Howard's The State of the Prisons, a footnote attached to a brief mention of a visit to the principal jail in Vienna. Told by his chaperone that no inmates there suffered from "putrid fever," Howard descends 24 steps into a series of dungeons and finds a man "loaded with heavy chains, and chained to the wall." ${ }^{\prime 34}$ The description sticks out for its attention to detail and for the sense of sympathy it conveys, unusual in Howard's text, for an individual weighed down by suffering. "Anguish and misery appeared with clotted tears on his face," Howard relates, and "he was not capable of speaking to me." ${ }^{\prime 35}$ Hayley's poem latches onto this vision of a "speechless Captive," as would many later writers who envisioned the prison reformer as an advocate for those prohibited from speaking for themselves. ${ }^{36}$

Bartolozzi's image of this prison visit-where sufferer, sympathetic reformer, and witnesses (including the reader) mirror each other's feelingsemblematizes the tear-filled prison reform verse of the late eighteenth century: Hayley's poet describes emotional relays that "Re-echoed thro' the heart." ${ }^{\prime 37}$ But Bartolozzi's engraving does more than document an elaborately felt scene. Done in a chiaroscuro style, the halo of light emanating from a hidden source behind the reformer's body provides a visual analog for the signature poetic figure in verse about Howard, what we call his aura. This many-layered trope-for its sentimental exuberance, one of the hardest for modern readers to digest-has its foundation in Howard's method of spotlighting and recording details, bringing inhumane conditions to light. As a figure of illumination, Howard's aura can be traced back to early eighteenth-century eulogies for Newton: poems of the 1720s by James Thomson, Richard Glover, and Allan Ramsay figure Newton radiating light and dissipating obscurity by linking the invisible power of gravity to "the secret hand of Providence. ${ }^{138}$ Howard's aura deviates from these earlier examples by combining illumination with the Greek meaning of "aura" as breathing and breezes. As Terry Castle points out, auras were common throughout Christian iconography, where they conveyed a "belief in the power of certain objects to work on others through the medium of the atmosphere. ${ }^{\prime \prime 39}$ Across the many panegyrics to Howard, the reformer's presence is invested with the power to dispel the unhealthy atmosphere in jails. In Hayley's Ode, Howard appears as a "Pure minister of light" whose "heavenly care / Has purg'd the damp of Death from that polluted air" of the dungeon. ${ }^{40}$ 




Fig. 2: Francesco Bartolozzi, "Vide Howard on Prisons. Page 82 Octavo Edition," in William Hayley, Ode Inscribed to John Howard, Esq. F. R. S. (London, 1780). Courtesy of the Huntington Library, San Marino, California.

Acting at times like a shield against contagion, Howard's aura emanates not just light but also effusions of sympathy, Christian piety, and, most importantly, pure, salubrious air.

First and foremost a poetic figure, Howard's aura fuses prison visits and empirical methods of data collection to broader concerns about overheated, airless places in Britain. In one of his most scathing critiques of Britain's prison system, Howard complains that in jails "methods are contrived to rob prisoners" of air, a necessary article of life "given us by Providence quite gratis, without any 
care or labor of our own." ${ }^{\prime 11}$ Hayley's Ode amplifies Howard's concern with access to air with a reference to Stephen Hales (1677-1761), a Fellow of the Royal Society and the inventor and principal proponent of ventilation mechanisms. To counteract corrupted air everywhere from dungeons and mines to ships en route to the tropics, Hales proposed installing bellows-driven ventilators that could exchange "great Quantities of bad, for good Air" - what he (like Howard after him) calls a "Cordial of Life." ${ }^{\prime 2}$ Appearing in Hayley's poem as Howard's "protecting angel," Hales's achievement is that he "taught the health-diffusing gales / Thro' Horror's murky cells to blow." ${ }^{\prime 43}$

In the late eighteenth century, to control airflow was to control both temperature and threats to health, most commonly the fevers associated with jails, hospitals, and other over-crowded spaces. As the Scottish medical doctor John Aitken (not to be confused with Howard's collaborator John Aikin) claimed in 1782 , the "temperature of atmospheric air, in temperate zones," could alleviate "febrile heat" if "freely applied, in a very powerful and constant manner." ${ }^{44}$ To produce and maintain temperateness, Hales recognized that ventilators would need a power source. On slave ships and other transport vessels, he explained, sailors could work the equipment; when installed in prisons and workhouses, ventilator systems could be powered by inmates with "full leisure to work the Bellows." ${ }^{45}$ Fitzgerald's 1761 plan for a metalline thermometer based on the measurement of extremes was a forerunner of Hales's device. Fitzgerald describes a rudimentary thermostat that would produce air circulation with a weight-driven ventilator, allowing for a fully automated system of monitoring and adjusting temperature. These apparatuses, Fitzgerald promised the members of the Royal Society, would maintain a botanical hot-house "within any two degrees of heat"; they would also efficiently counteract the "over-heated air" in places "where large assemblies are collected, and obliged to remain a long time" without the "danger of suddenly throwing in too great a quantity of cold air" all at once. ${ }^{46}$

While poems about Howard traffic in sentimental mystification, they just as often amplify desires inherent in the idea of ventilation as a medicotechnological cure. In the verbal rendering of the "speechless Captive" scene from its frontispiece, Hayley's poet addresses the reformer's power in this way:

Thine eye his dumb complaint explores;

Thy voice his parting breath restores;

Thy care his ghastly visage clear

From Death's chill dew, with many a clotted tear,

And to his thankful soul returning life endear. ${ }^{47}$

Howard's eye first brings light to the dungeon, making the prisoner's complaint visible. Having illuminated the space of the cell, his voice returns air to the room, allowing the prisoner to breathe while simultaneously evaporating the cold and 
damp that forebodes his demise. Like a self-regulating ventilator, Howard's presence dispels "Contagion's baleful breath" and returns safety and life to a place that was, moments before, "the hideous cave of Death." ${ }^{\prime 4}$ In Samuel Jackson Pratt's The Triumph of Benevolence (1786) - a poem intended as an inscription on a proposed statue of the reformer to be erected in London-images of Howard bringing food to prisoners or freeing them from jail give way to climatic cause and effect: the "deadly Venom" that "poisons now the gale" is diffused by "newborn Zephyrs ... taught to blow" by Howard, with the result that "Where the Heart sickens, genial Heath prevail!" ${ }^{49}$ Following Aitken's prescription for a thermometric balance, Pratt's poem envisions Howard "as by touch divine" dispelling "FEVER, that seizes on the burning breath; / The ICY POWER, that kills with shivering sighs." ${ }^{150}$ A 1789 imitation of Pratt's poem consolidates the figures of sympathy, legal redress, physiological cure, and Christian benevolence by asking those "reprieved into the open air" to "Behold the Man—whose heart felt all your ills, / Who fann'd your fever with celestial joy!"51 In these poems Howard appears as a human ventilator of divine aspect, dissipating thermometric extremes and infusing jails with healthful, temperate air.

Howard's aura and its atmospheric effects were not confined to the prisons he visited during his tours of Britain and Europe. Following the logic of medical writing that equated noxious air in jails with that of the tropics, poets used Howard's travels to extend the reach of ventilation's curative potential. Underscoring philanthropic aims, poems often juxtaposed Howard's wide-ranging travels to those of traders and colonial agents intent on making money-"slaves of gold" as Pratt termed them-or, on the other end of the spectrum, with aristocratic gentlemen on the grand tour. ${ }^{52}$ As Cowper concluded in his 1782 long poem, "Charity," the reformer left England's rural bliss to "traverse seas, range kingdoms and bring home / Not the proud monuments of Greece and Rome / But knowledge such as only dungeons teach. ${ }^{\prime \prime 3}$ Howard's global mission, however, was most often measured in climatological terms that privileged temperateness as both a thermometric and humanitarian ideal. Hayley's Ode offers Howard as an example of "Philanthropy outstrip[ping] keen Pleasure's pace, / When with a warmer soul she ran a nobler race!"54 In Darwin's vision, "O'er burning sands, deep waves, or wilds of snow, / Thy HOWARD journeying seeks the house of woe," while for Pratt, Howard's "soul" moves by a diffusion of mild weather that "Girding creation in one warm embrace, / Extends the saviour arm from pole to pole. ${ }^{\prime \prime 5}$ Howard's presence diffuses temperateness everywhere for the benefit of all people. Much as the power of Newton's mind ranged the universe in early eighteenth-century verse, poets invented Howard as a "friend to every clime!" whose influence touched "all lands, where'er the tear." ${ }^{\text {"56 }}$ The link between ventilation technology and wide-ranging reformist impulses was strengthened by Howard's prison visits across Europe and the East. But that conjunction, poets insisted, held out a promise to the wider world that physical conditions could be controlled and dangerous extremes avoided no matter where they appeared. 
These figurations of Howard's ability to counteract climatic extremes cannot be isolated from the map of the world's diseased regions-a cartography of pestilence wherein ventilation "took on an almost mythical status." 57 As Bewell notes, medical geography was closely allied with anxieties in Britain about the epidemiological consequences of colonialism, particularly anxieties that "England-or at least certain social groups within England-might be tropicalized." 58 Such concerns about the consequences of colonial imports-whether diseases, climate, commodities, or people-raised questions about the continued viability and moral standing of Britain's colonial enterprise. One response to these concerns, as Deirdre Coleman has argued, was a body of visionary writing about new settlements that sought to recast Britain's imperial agenda and influence on the world following the American Revolution. Encompassing penal reform and anti-slavery writing, "romantic colonization" projected utopian visions of the social and economic benefits of colonization for both colonizers and colonized. ${ }^{59}$ As Tim Fulford, Debbie Lee, and Peter Kitson have shown, this ideological turn was driven in part by literature's engagement with science and exploration: authors like Cowper learned to see the world "through the eyes of explorers and scientific writers who worked in the service of empire," and in so doing discovered their "human kinship" with unknown, faraway people "whom Britons had, hitherto, been exploiting with few qualms." 60 The archive of poetry about Howard, which helped pave the way for the outpouring of antislavery verse in the following decade, suggests another, simultaneous direction for this process. ${ }^{61}$ Howard's recourse to a thermometric standard encouraged the poets' projection of an ideal of temperateness into irregularly managed jails and, subsequently, onto the entire globe. In poetry, Howard's influence knew no limits: "Onward he moves!" Darwin exclaims, "-Disease and Death retire" as he continues "traversing the globe" arrayed in "VIRTUE's purest robe." 62 In Such Things Are, Inchbald locates Howard (represented as Mr. Haswell in the play) in Britain's colonial outpost in Sumatra, not knowing, as she put it, "what part of the East the hero of the present piece was [at the time the play was written] dispensing his benevolence." 63 That Howard never traveled to Indonesia or any colonial settlement in the tropics was of no consequence; following his travels abroad-which were in fact mainly confined to Western Europe-literary authors extrapolated prison reform into a much larger operation, an attempt to "free the prison of the globe," a tireless, world-spanning journey of empirically grounded atmospheric benevolence. ${ }^{64}$ By figuring Howard as an agent of ventilation exported from Britain to its colonies and subsequently across the entire planet, authors sought to allay anxieties about the medical and moral consequences of colonialism and to promote Britain's continuing colonial agenda of exploration and settlement. ${ }^{65}$

The elegies that followed Howard's death in the Ukraine in 1790-an event perceived by many as martyrdom-reiterate and heighten this vision of benevolent empire by positing an eastward proselytical agenda underwritten by 
thermometric imagery. Bowles's The Grave of Howard (1790) begins by lamenting "he that wander'd o'er the world alone / List'ning to Misery's universal moan; / He, who sustain'd by Virtue's arm sublime, / Tended the sick and poor from clime to clime." Here, Howard's aura has enough force to arrest both human and climatic violence: just as the "embattled clouds" of a northern tempest retire from his path, the "Barbaric legions train'd to spoil and blood / Heart-struck, and wond'ring, and relenting, stood" upon seeing Howard perform "Mercy's great behests." Asia brings temperate weather while also tempering the warlike character of Cossacks and Tartars; as Howard changes the climate, he also changes the people he encounters. Perhaps the most exaggerated expression of this transformative aspect of Howard's aura came from the pen of the Welsh attorney and zealous Methodist Walter Churchey. In a 1789 self-published book of poems vetted by Cowper and John Wesley, Churchey describes the effect Howard's (ultimately never erected) marble effigy might have on a "turban'd Moor" in London who has been "reprieved into the open air": dropping before the statue "In spite of Mahomet," the Moor sheds a tear that streaks a "milk-white passage down his cheek," thus silently "thank[ing] the man / Who, like the Saviour of a shatter'd world, / Met Death itself, to save a sinking land." ${ }^{\prime 67}$ The passage inscribes religious and racial difference and simultaneously negates it through a mutual agreement about the power of atmospheric change: Moor and Methodist acknowledge the health of Britain's temperate climate, the "open air" of London, which Howard reproduced everywhere with his global philanthropic mission. By embodying the technology of ventilation, Howard had become a figure for global peace and unity. But as a selection from The Poetry of The World (1791) confirms, such unity, as a matter of course, rests on and reaffirms Britain's imperial power: Howard was "DEAR to mankind —-to Briton's doubly dear, / Whom Christians love, and Infidels revere." ${ }^{\prime 68}$

Before and after his death, Howard's aura expressed hope about the portability and reproducibility of temperateness, a salubrious British export to the diseased portions of the globe. However, the increasing emphasis on Howard's religious zeal in poems published after his death reflects another facet of his public character-his famous, even notorious, personal habits. After his death, rumors emerged that the regime of extreme discipline he imposed on his son drove the youth to the madhouse and, eventually, to suicide. ${ }^{69}$ Posthumous discussions of Howard harped on his eccentricities, specifically his abstemiousness and asceticism, which were, like his data collecting strategies and philanthropic mission, coded in thermometric language. While poetry celebrated Howard's mixture of empirical methods and religious zeal and deployed it to recast Britain's imperial project, prose works appearing after Howard's death took a more skeptical view of this conjunction. Exposing these "personal singularities" in a memoir, Pratt-a literary opportunist and, at one time, Howard's most vocal panegyrist—explained that this famous man "preferred damp 
sheets, linen, and cloaths, to dry ones, and both rising and going to bed swathed himself with coarse towels dipped in the coldest water he could get." He was a man, Pratt adds, who "never put on a great coat in the coldest of counties" and who, punctual as always, appeared for a visit with Pratt in London completely soaked from head to foot and unmindful of his condition. ${ }^{70}$ It is one thing, Pratt shrewdly implies, to radiate with a protective aura on the pages of poetry, and something else altogether to act as if you did in everyday life.

\section{DISCIPLINING THE ECCENTRIC ENTHUSIAST}

Howard's final publication, An Account of the Principal Lazarettos of Europe (1789), vindicates his choice to go forward with an expedition to Russia and Turkey, which had recently suffered plague outbreaks. Howard left England for these regions trusting, he explains, "in the protection of that kind Providence which has hitherto preserved me." Aware that such claims bordered on excessive zeal, he asks readers not to impute his conduct to "rashness or enthusiasm" but rather to "a serious, deliberate conviction that I am pursuing the path of duty."71 In this self-defense, Howard recognized what would become the central point of contention over his character: was his unwavering pursuit of facts a sign of his pious devotion to a philanthropic mission? Or did it register an "eccentric enthusiasm, which ... happened to take a fortunate turn, the gratifications of his private taste producing salutary consequences for the publick" ${ }^{72}$ In light of Howard's iconic status, answering this question had consequences not only for the public appeal of reform movements, but also for the professional aspirations of those associated with the prison reform cause. Following the lead of the poems discussed above, posthumous prose writing about Howard exploited the rhetoric of temperature to distinguish the rational from the irrational and to lodge him in one category or the other. This strategy takes on special urgency in the official biography of Howard by Aikin. A View of the Character and Public Services of the Late John Howard (1792) rehearses these debates, defending the reformer from charges of overheated enthusiasm while simultaneously legitimating the medical professional by labeling Howard as merely a useful fact collector and amateur philanthropist.

Howard and his advocates often claimed that the reformer's temperance and virtuous purity shielded him from danger as he traveled. But periodical accounts appearing after his death pointed out that warm feelings of benevolence could quickly rise to fanatical excess, and specifically enthusiasm. Aikin closes his biography with an extended defense of the renowned philanthropist from these precise charges. Early on, the biography describes Howard's religious affiliations: while many of his friends (including Price and Aikin himself) were Rational Dissenters and The State of the Prisons was published by the dissenting publisher William Eyres at Warrington, Howard was a moderate Calvinist in belief and a member of a Baptist congregation in London. Howard was, accord- 
ing to Aikin, "less solicitous about modes and opinions, than the internal spirit of piety and devotion" and the "zeal and sincerity" of belief. ${ }^{73}$ At the close of the biography, Aikin returns to this topic, admitting that while Howard had some peculiar habits, his "cool and steady temper" was not touched by "that heat and eagerness, that inflamed and exalted imagination, which denote the enthusiast." The aspersions Howard had suffered at the hands of "men of cold hearts and selfish dispositions" were mistaken; if anything, Howard "felt as men should feel" - neither frigid nor overheated, but temperate in all things. ${ }^{74}$ A Rational Dissenter, Aikin understood that a potent and long-established counter to accusations of enthusiasm was not to be found in Howard's sensibility or Christian benevolence, but in his rational, scientific methods. Since reason's cooling effect could put out charges of over-heated enthusiasm, it could also re-inscribe Howard within the bounds of social and religious propriety. Accordingly, posthumous defenders-including Hayley, Aikin, and the radical reformer and poet John Thelwall-all emphasized his contributions to the Royal Society, his laborious accuracy in collecting data, and his reliance on direct observation, the foremost tenet of Baconian induction.

This strategy, however, had the potential to backfire. J. G. A. Pocock explains that as early as the mid-seventeenth century it become apparent "that there could be such a thing as a materialist enthusiasm," a development that "underlines the extent to which the diatribe against enthusiasm was moving away from its original concern with the excesses of the prophetic and the Pentecostal, to fasten upon heresy and error at the level of the philosophical."75 Indeed, as the eighteenth century progressed, the critique of enthusiasm shifted from a theological to a medico-scientific register with unsettling consequences. Perhaps empirical methods of collecting and arrangement could be carried too far, constituting a kind of madness in which "the rational self became a self effaced by rationality."76 This was certainly the case with some eighteenth-century weather observers like Thomas Barker, the squire of Lyndon Hall and correspondent of Gilbert White. As Golinski describes, Barker kept a journal of observations for sixty years running, "twice a day, month after month, year after year . . read[ing] his thermometer and barometer, at times that he measured to the minute by his clock." Such practices manifested a kind of "hyper-rationality," one that seemed-to some contemporaries, including Johnson-fanatical, a symptom of "an almost pathological concentration on minute incidentals."77 The biographical notices published after Howard's death uniformly cast his character, positively or negatively, in the same mold as Barker and other data collectors. Howard's habit of meticulous recording was the hallmark of his prison visits and his personality partook of his methods: he had a "love of order and regularity" and "his disposition of time was exact and methodical" —so much so that, as Aikin remarked, "he would suffer nothing to interrupt for a moment, the main object of his pursuit." ${ }^{78}$ Howard's meticulous records demonstrated devotion to a cause, but like Herman Melville's Ahab, 
these habits also showed signs of monomania-the drive to pursue his object around the globe even if such efforts would eventually claim his life.

For many of his contemporaries, "constancy of mind" and a "resolute temper" marked Howard as an empirical enthusiast, one whose over-reliance on rationality was a visible symptom of a diseased mind and corrupted reason. ${ }^{79}$ Howard's known indifference to authority and support of democratic principles at least partially explain the vehemence with which his character was both defended and disparaged in the early 1790s.$^{80}$ However, Aikin's ambivalent treatment of Howard in his biography was more professionally than politically motivated. For much of the century, enthusiasm had been deployed to "marginalize and thereby silence, according to class or gender or cognitive mode or religious affiliation"; such strategies were as productive as they were repressive when they helped "constitute disciplines . . . against threatening forms of unchanneled energy." ${ }^{\prime 1}$ The cognitive mode of Howard's empiricism presented specific challenges to nascent disciplinary formations, particularly the medical profession from which he was explicitly excluded.

The new evidence-based medicine or medical arithmetic that arose in the second half of the eighteenth century-developed by James Lind, John Coakley Lettsome, John Millar, John Gregory, George Fordyce, and Aikin himselfrelied on retrospective quantitative analyses of case studies and comparative therapeutic trials. The movement evolved in reform-oriented Dissenting communities outside the London medical establishment of the College of Physicians, and it constituted a key force in the transformation of medicine into a modern profession. As discussed above, Howard clearly borrowed his quantitative methods and rhetoric from this movement, but his reliance on Aikin's work is even more direct. Aikin's Thoughts on Hospitals, published two years before Howard started his prison inspections, makes arguments about temperature and air circulation that would ground Howard's claims. Aikin suggests that choosing a "proper situation" for a hospital should be based on "the state of the air, as depending on heat and cold, dryness and moisture" and the design of the interior "leave as much vacant space, occupied by the fresh air alone circulating freely, as was in any degree compatible with use and convenience." Aikin also compared the conditions in hospitals to those of jails: he laments that when a person "walks though the long wards of a crowded Hospital, and surveys the languid countenances of the patients, . . . he will be apt to look upon a Hospital as a dismal prison, where the sick are shut up from the rest of mankind to perish by mutual contagion." In such a place, the "grand necessary of life, air, is never to be had in a salutary degree of purity, frequently is vitiated so as to become poison. Every hospital, I fear, without exception, may in some measure be considered as a Lazaretto, having its own peculiar disease within it. ${ }^{\prime 82}$ Howard's methods and reliance on a thermometric standard thus directly aligned his work with the new quantitative medicine, and he was explicitly recognized as a contributor to the movement. Just days before his departure 
for the East in 1789, Lettsome conveyed an honorary membership to the Medical Society of London to Howard for his "very useful and important labours respecting the plague, confinement, air, cleanliness, and the circumstances, connected with the Medical arts." 83 Despite this overture, the professional aspirations of this new order of physicians also made Howard an anathema to their cause. Howard's willingness to experiment on his own body and his selfproclaimed "Christian profession" brought the enthusiast's zeal uncomfortably close to the medical professional's empirical investigations. As a consequence, in their letters to Howard before his departure in 1789 both Aikin and Lettsome request that he convey to them not his own observations, but information collected from "sensible judicious Physicians or Surgeons, with their names in full, and their respective Titles, as Professors, or Academicians, \& etc." ${ }^{84}$ This tension between fact collector and medical professional plays out in Aikin's clinical diagnosis of Howard's last illness, a textual dissection that insists on treating Howard as an amateur without institutional sanction.

Aikin uses a scuffle between Howard and the College of Physicians to demarcate licensed professional from amateur experimentalist. In order to advance "the reformation of morals in our prisons," Howard's Lazarettos concludes with a draft of a bill proposing a legal ban on spirituous liquors in prisons. Such a proposal was not without its detractors, including members of the College of Physicians, a contingent Howard directly addresses in his text: "If the Gentlemen of the Faculty, and others, still object to the exclusions of all fermented liquors from jails, under the idea that their use is in some measure necessary as antiseptics, I would desire them to consider, that by the proposed dietary prisoners are to have a warm dish, chiefly of vegetables, twice a day." ${ }^{\prime 85}$ Conventional medical wisdom ascribed antiseptic properties to alcohol for its ability to counteract putrefaction, whether the body's "putrid state" was caused by bad meat, corrupted air, or tropical climate. ${ }^{86}$ However, some argued the antiseptic properties of vegetables were more efficacious and Howard fell into this camp for moral as much as medical reasons. Drawing on the ideal of temperateness, Howard's proposed legal reforms pitted his celebrity against the mandates of London's foremost medical authorities.

Himself barred from fellowship in the College of Physicians because he took his degree at Leyden, Aikin nonetheless sides with the College, going so far as to suggest that Howard's judgment was "warped" on this point because he was "under the influence of his own peculiar habits of life." in opinion sets the stage for Aikin's account of Howard's last illness. Aikin first relates a sparse narrative: Howard came into contact with a sick woman on December 27, and on January 8 he found himself unwell, upon which he "immediately took some Sal Volatile [smelling salts] in a little tea"; not finding himself better in several hours, he repeated the dosage. Suffering a violent fever the next night, "he had recourse to his favorite remedy, James's powder [a popular concoction of mercury, arsenic, and sulfur], which he took regularly every two 
to four hours till Sunday the 17 th. ${ }^{\prime \prime 8}$ After a series of fits in the following days, Howard died on January 20, 1790. Rather than turning to the sentimental language employed in eulogies of Howard, at this point Aikin instead shifts into a professional mode, stating that he will "only make a medical remark or two" on the events described. Having already pointed out that Howard's "own prescriptions were never interfered with during this time," Aikin disputes Howard's judgment about the cause and type of disease he had contracted on the basis of its symptoms, concluding that "the long and frequent use of James's powders must have been prejudicial." ${ }^{\prime 89}$ By self-medicating — with a potentially deadly concoction - and not seeking the advice of a legitimate doctor, Howard had, in effect, killed himself.90

In Aikin's account, Howard stands as an "empiric"-a person defined in Johnson's Dictionary as "a trier or experimenter; such persons who have no true education in, or knowledge of physical practice, but venture upon hearsay and observation only."91 A revamped version of Swift's absurd projectors in Gulliver's Travels (1726), Howard ventures into medicine with an experimentalism gone awry for lack of deep knowledge. This problem, Aikin implies, arose when Howard stepped out of one sphere into another-specifically when he moved from collecting data to experimenting with diagnosis and treatment. ${ }^{92}$ Howard, Aikin asserts, was not a man with "that extensive comprehension, that faculty of generalizing, which is said to distinguish the man of genius," but he did collect "a body of information, which has made even professional men acquainted with interesting facts that they never before knew." ${ }^{\prime 93}$ As long as he continued to collect data, Aikin implies, Howard could be of use to the medical profession; when he began to act as if he were a professional, he became dangerous and self-destructive.

As a data collector, Howard occupied the position of an eighteenth-century "knowledge-worker," a largely self-taught, institutionally unsanctioned individual who played a vital role in the production of knowledge..$^{94}$ A growing body of scholarship, to which this essay contributes, has begun to examine figures like Howard-weather observers, archeological fieldworkers, artists traveling with scientific expeditions, native informants, slaves employed as botanical collectors-who were enabled and empowered by structures foreign to modern specialized disciplines but nonetheless fomented the movement toward professionalization, regulation, and control. ${ }^{95}$ With his combination of class status, methodology, philanthropic aims, literary celebrity, and pious devotion to the cause of prison reform, Howard was able to forward a reformist agenda with or without the backing of established authorities. Read as an exercise in professional legitimation, Aikin's biography of the celebrated reformer responds to this unsettling conjunction of forces with a two-pronged attack. Aikin deploys thermometric language to detach Howard's methods from the charge of religious enthusiasm: over-heated religious zeal can be tempered and made temperate by the procedures of experimental science. To counteract the 
possibility that empiricism itself might boil over into madness, Aikin carefully distinguishes the mechanical pursuits of the fact collector from the labor of synthesis performed by the professional. By turning Howard into a medical case study, Aikin strips him of the cultural and political authority he had attained during his life, reinserting him postmortem into the conventional hierarchy of amateur collector as helpmeet to the professional man of science.

Howard has been renowned since his own time to the present day for his philanthropic efforts on behalf of prisoners, and he continues to be recognized in the Howard Journal for Criminal Justice, a peer-reviewed, international social science journal first published in 1921 and now appearing under the auspices of the Howard League for Penal Reform. In this guise, Howard's legacy promotes dialogue between academics, policy makers, and legal professionals while upholding a standard of scholarly research—a standard underwritten by the very methods of data collection and analysis that he had practiced and popularized. To deploy Howard's name in this way today depends, to a large degree, on the erasure of his enthusiastic embrace of his "Christian profession"; it takes for granted what Aikin worked to instantiate, the distance between empirically grounded reform and religious fanaticism. As we have shown, in Howard's own historical moment it was precisely this confluence of religious and scientific clout that allowed him to achieve an iconic status in the cultural imagination and to garner a measure of real power in medical and legal arenas. Thermometrics intertwined debates over prison conditions, climate control, medical geography, and religious zeal—a convergence that made it possible for Howard to serve as both a divinely inspired symbol of Britain's new benevolent empire and a case study in amateur experimentalism that legitimated the new medical professional.

\section{NOTES}

This essay benefitted from the comments and advice of colleagues and anonymous reviewers. In particular, we would like to thank Jay Clayton, Tim Fulford, Nora Gilbert, Noah Heringman, Rachel Teukolsky, and Kelly Wisecup for their input on earlier versions of the essay.

1. John Howard to Richard Price, 22 September 1789, quoted in John Aikin, A View of the Character and Public Services of the Late John Howard, Esq. LL. D. F. R. S. (London, 1792), 188.

2. Erasmus Darwin, The Botanic Garden, Part II. Containing the Loves of the Plants, a Poem (Litchfield, 1789), lines 436-42. Unless otherwise noted, citations will be given by line number.

3. For discussions of pre-disciplinarity, see Luisa Calè and Adriana Craciun, "The Disorder of Things," Eighteenth-Century Studies 45, no. 1 (2011): 1-13; and Noah Heringman, Sciences of Antiquity: Romantic Antiquarianism, Natural History, and Knowledge Work (Oxford, 2013), 1-21.

4. For an account of physico-theology, see Robert Markley, Fallen Languages: Crises of Representation in Newtonian England, 1660-1740 (Ithaca, 1993). On the status of miracles as 
scientific evidence in the seventeenth century, see Lorraine Daston, "Marvelous Facts and Miraculous Evidence in Early Modern Europe," Critical Inquiry 18, no. 1 (1991): 93-124. For an account of weather observers' connection to spiritual autobiography, see Jan Golinski, British Weather and the Climate of Enlightenment (Chicago, 2007).

5. As Margot C. Finn has shown in her Character of Credit: Personal Debt in English Culture, 1740-1914 (Cambridge, 2003), it is crucial to recognize the role played by debtors in prison history and prison reform efforts. Howard's reform proposals, as she points out, consistently represented debtors as "a distinct and rightfully privileged constituency" in need of help, not punishment (158). The mixture of empiricism and Christian charity we are focusing on here reflects the porousness of a prison world that contained debtors as well as criminals.

6. The clearest example of this elision might be Rod Morgan's thoroughgoing attempt to explain why Howard, for all his shortcomings as an author, rose to great prominence. Morgan provides a helpful catalog of "events that coincided with the publication" of The State of the Prisons in the 1770s and 1780s. By dissolving Howard's fame into a "general resonance" with widespread concerns, Morgan's study covers over the fact that poets actively used Howard's person and activities to create this "powerful amalgam" ("Divine Philanthropy: John Howard Reconsidered," History 62, no. 206 [1977]: 388-410, 389, 398).

7. Howard, The State of the Prisons in England and Wales, with Preliminary Observations, and an Account of Some Foreign Prisons [1777], 3rd ed. (Warrington, 1784), 2.

8. R. W. England, "Who Wrote John Howard's Text?: The State of the Prisons as a Dissenting Enterprise," British Journal of Criminology 33, no. 2 (1993): 203-15, 204.

9. Aikin describes the process of composing The State of the Prisons as a collaborative endeavor: "On his return from his tours he took all his memorandum books to an old retired friend of his, who assisted him in methodizing them... They were then put into the hands of Dr. Price, from whom they underwent a revision, and received occasionally considerable alterations." Howard then took the manuscript to the press at Warrington, where he and Aikin read it over together, "sheet by sheet" (View, 199, 64-65).

10. William Guy, "John Howard as Statist," Journal of the Statistical Society of London 36, no. 1 (1873): 1-18, 1. Guy was a Professor of Hygiene at King's College London and the Vice President of the Statistic Society; his article celebrates Howard's method of collating data to counter the charge, made by Aikin, that Howard lacked proficiency in science. We will return to the source of Aikin's claim below.

11. Edmund Burke, A Speech of Edmund Burke, Esq. at the Guildhall, in Bristol, Previous to the Late Election in that City (London, 1780), 25.

12. Burke, 25.

13. For a survey of early attempts at prison reform in Britain, see Alexander Pitofsky, "The Warden's Court Martial: James Oglethorpe and the Politics of Eighteenth-Century Prison Reform," Eighteenth-Century Life 24, no. 1 (2000): 88-102.

14. Mary Poovey, A History of the Modern Fact: Problems of Knowledge in the Sciences of Wealth and Society (Chicago, 1998).

15. Barbara Shapiro, Probability and Certainty in Seventeenth-Century England (Princeton, 1983), 20.

16. On this development, see J. L. Heilbron, "Introductory Essay," in The Quantifying Spirit in the 18th Century, ed. Tore Frängsmyr, Heilbron, and Robin E. Rider (Berkeley, 1990), 1-23; Ulrich Tröhler, "To Improve the Evidence of Medicine": The 18th-Century Origins of a Critical Approach (Edinburgh, 2000); and Andrea Rusnock, Vital Accounts: Quantifying Health and Population in Eighteenth-Century England and France (Cambridge, 2002).

17. Richard Price, Observations on Reversionary Payments (London, 1771), iv-v.

18. Aikin, View, 22.

19. Aikin, "Remarks on the Memoirs of the late John Howard, Esq.," Walker's Hibernian Magazine, or, Compendium of Entertaining Knowledge (May 1790): 428-30; W. Watson to Howard, 28 February 1789, Papers of John Howard, MS Eng. Misc. c. 332, Bodleian Library 
Special Collections, Oxford University. Watson's letter begins, "I am highly obliged to you for your observations of the late cold, which exceeds what we usually find in our climate" and goes on to give a series of detailed readings.

20. For warm baths, see Howard, Prisons, 3rd ed., 28; on warm soup, see Howard, Prisons, 3rd ed., 40; on airy, ventilated rooms, see Howard, Prisons, 3rd ed., 21, 63, 75, 77; on the Bastille, see Howard, Prisons, 3rd ed., 175.

21. Howard, Prisons, 3rd ed., 272.

22. Howard, Prisons, 3rd ed., 173.

23. For criticism of close, hot prisons, see Howard, Prisons, 3rd ed., 87, 163, 282, 433, 467; for the importance of fresh air to health, see Howard, Prisons, 3rd ed., 6-8.

24. Edmund Halley, "An Account of Several Experiments Made to Examine the Nature of the Expansion and Contraction of Fluids by Heat and Cold, in Order to Ascertain the Divisions of the Thermometer, and to Make That Instrument," Philosophical Transactions 17 (London, 1693): 650-56, 655.

25. See Howard, Prisons, 3rd ed., 95, 105.

26. Hasock Chang, Inventing Temperature: Measurement and Scientific Progress (Oxford, 2004), 10.

27. Golinski notes that eighteenth-century weather observers often synthesized their systematic daily measurements into seasonal or monthly summaries emphasizing abrupt changes and extreme conditions (142-50).

28. Keane Fitzgerald, "A Description of a Thermometer and Barometer," Philosophical Transactions 52 (1761-62): 146-54, 148.

29. Golinski, 110.

30. Alan Bewell, Romanticism and Colonial Disease (Baltimore, 1999), 18-19, 28. Also see Rajani Sudan, "Chilling Allahabad: Climate Control and the Production of Anglicized Weather in Early Modern India," Journal for Early Modern Cultural Studies 8, no. 2 (2008): 56-73, 61-62.

31. Golinski, 148-56.

32. Tröhler, 29-31.

33. Howard, Prisons, 3rd ed., 3.

34. Howard, The State of the Prisons in England and Wales, 2nd ed. (Warrington, 1780), 82. In the third edition of 1784 , this note was moved into the main text; see Howard, Prisons, 3rd ed., 103.

35. Howard, Prisons, 3rd ed., 103.

36. William Hayley, Ode Inscribed to John Howard, Esq. F. R. S. (London, 1780), 8. Moira Ferguson has pointed out the crucial but politically problematic role that speechless captives play in the "abolitionist shorthand" employed by Hannah More and other poets who wrote against slavery in the decades to follow ("British Women Writers and an Emerging Antislavery Discourse," The Eighteenth Century: Theory and Interpretation 33, no. 1 [1992]: 3-23, 3-4).

37. Hayley, 8.

38. James Thomson, A Poem Sacred to the Memory of Sir Isaac Newton (Dublin, 1728), 6.

39. Terry Castle, The Female Thermometer: Eighteenth-Century Culture and the Invention of the Uncanny (New York, 1995), 32.

40. Hayley, 12.

41. Howard, Prisons, 3rd ed., 8.

42. Stephen Hales, A Description of Ventilators (London, 1753), iv-vi.

43. Hayley, 9.

44. John Aitken, Elements of the Theory and Practice of Surgery (London, 1782), 236-37.

45. Hales, 22.

46. Fitzgerald, 153.

47. Hayley, 8.

48. Hayley, 12. 
49. Samuel Jackson Pratt, The Triumph of Benevolence; a Poem. Occasioned by the National Design of Erecting a Monument to John Howard, Esq. (London, 1786), 12.

50. Pratt, Triumph of Benevolence, 13.

51. William Churchey, "Lines for the Statue of Mr. Howard," in Poems and Imitations of the British Poets (London, 1789), 637.

52. Pratt, Triumph of Benevolence, 9.

53. William Cowper, "Charity," in Poems (London, 1782), 195.

54. Hayley, 13.

55. Darwin, 441-42; Pratt, Triumph of Benevolence, 7.

56. Hayley, 13.

57. Bewell, 31-32.

58. Bewell, 17-18, 20.

59. Deirdre Coleman, Romantic Colonization and British Anti-Slavery (Cambridge, 2005), $2-3$.

60. Tim Fulford, Debbie Lee, and Peter J. Kitson, Literature, Science, and Exploration in the Romantic Era: Bodies of Knowledge (Cambridge, 2004), 17-18.

61. A detailed discussion of the connections between prison reform verse and antislavery verse is beyond the scope of this essay. However, both bodies of poetry draw on a common stock of metaphors and figures, including a rapacious Empire, foul enclosed places, and the broken family. Some poets, such as Cowper and Anna Barbauld, linked the two agendas in individual poems; others-including William Lisle Bowles, Robert Merry, Pratt, Darwin, and Robert Southey-produced collections or longer works that contain verse on both topics; and anthologies (such as Knox's Elegant Extracts) grouped prison reform and anti-slavery poems together.

62. Darwin, Loves, 467, 461-62.

63. Elizabeth Inchbald, Such Things Are, A Play, In Five Acts (London, 1788), n.p.

64. Hayley, 15.

65. Anna Seward's Elegy on Captain Cook was published in the same year as Hayley's Ode and much admired by Hayley. This poem also uses thermometric imagery to make a similar claims about James Cook's range of influence: Cook had braved "The scorch'd Equator, and the Antarctic wave" at the call of "HUMANITY," which led him to "strew her soft comforts" to the "shiv'ring natives of the frozen zone, / And the swart Indian, as he faintly strays / 'Where Cancer reddens in the solar blaze'" (Elegy on Captain Cook [London, 1780], 4-5). The tragic outcome of Cook's voyage, however, made it impossible for Seward to make claims for its ultimate success. Howard had read the 1788 biography of Cook by Andrew Kippis and extracted strictures from its narrative, including the ideal of remaining "Cool \& intrepid among dangers" (Papers of John Howard, Philanthropist, 1718-1800, Mss. 42396, 36, "Memorandums and Remarks, 1788, 1789," Bodleian Library Special Collections, Oxford University).

66. William Lisle Bowles, The Grave of Howard (Salisbury, 1790), 2, 5.

67. Churchey, 637.

68. "To the Memory of Mr. Howard," The Poetry of the World (London, 1791), 90.

69. This claim appears in a number of periodical notices, as well as in an anonymous biography, which notes that critics "less warmly attached to [Howard's] good qualities impute the misfortune of the son to the rigorous exertions of paternal authority" (The Life of the late John Howard Esq. with a Review of his Travels [London, 1790], 71).

70. Pratt, Gleanings Through Wales, Holland, and Westphalia, vol. 1 (London, 1795), 216, 218.

71. Howard, An Account of the Principal Lazarettos in Europe; with Various Papers Relative to the Plague (Warrington, 1789), 235, original emphasis.

72. “Character of Mr. Elwes," The Gentleman's Magazine (Oct. 1791): 906.

73. Aikin, View, 19-21.

74. Aikin, View, 212-13, 215. 
75. J. G. A. Pocock, "Enthusiasm: The Antiself of Enlightenment," in The Certainty of Doubt, ed. Miles Fairburn and W. H. Oliver (Wellington, 1996), 117-39, 126.

76. Lawrence E. Klein and Anthony J. La Vopa, introduction to Enthusiasm and Enlightenment in Europe, 1650-1850, ed. Klein and La Vopa (San Marino, 1998), 1-5, 5.

77. Golinski, 88.

78. "Some Account of the late celebrated John Howard, Esq.," Weekly Entertainer 20, no. 503 (24 Sept. 1792): 310; Aikin, "Remarks," 428.

79. Aikin, View, 214, 216.

80. John Thelwall in particular draws attention to Howard's refusal to "fawn to greatness," claiming that he "placed himself on a level with all mankind, and treated all with the same degree of civility and attention" (An Interesting Collection of Modern Lives [London, 1792], 9-36, 34).

81. Klein and La Vopa, 5 .

82. Aikin, Thoughts of Hospitals (London, 1771), 13, 9-10.

83. John Coakley Lettsome to Howard, 18 June 1789, Papers of John Howard.

84. Lettsome to Howard, 18 June 1789, Papers of John Howard; see also Aikin to Howard, 20 June 1789, Papers of John Howard.

85. Howard, Lazarettos, 235, original emphasis.

86. For example, military surgeon John Bell deemed beer "absolutely necessary to preserve the vigour of the body against the debilitating influence of a tropical climate" (An Inquiry into the Causes which Produce, and the Means of Preventing Diseases Among British Officers, Soldiers, and Others in the West Indies [London, 1791], 60). Naturalist and physician Johann Zimmermann recommended "an antiseptic diet" including fermented liquor to counteract the "confined and corrupted air" which produced jail fever (A Treatise on Experience in Physic, 2 vols. [London, 1778], 2:121).

87. Aikin, View, 179. For Aikin's relation to the College of Physicians, see Lucy Aikin, Memoir of John Aikin, M. D. (London, 1823), 174-76.

88. Aikin, View, 192-93.

89. Aikin, View, 196-97.

90. Aikin was probably right: Dr. Robert James's Fever Powders caused vomiting and purging accompanied by sweat and salivation. In large or repeated doses, unconsciousness and death followed. The powder reached the apex of its popularity in the 1760s (when patients demanded its prescription), but reputedly caused Oliver Goldsmith's death in 1774. See Jonathan Andrews and Andrew Scull, Customers and Patrons of the MadTrade: The Management of Lunacy in Eighteenth-Century London (Berkeley, 2003), 153. In 1790, medical professional James Adair recognized the popularity of this concoction and warned that physicians "are better qualified than ignorant attendants to superintend and regulate its operation" (Essays on Fashionable Diseases [London, 1790?], 202).

91. Samuel Johnson, A Dictionary of the English Language, 2nd ed. (London, 1755-56).

92. By the mid-nineteenth century, Aikin's distinction would become a professional standard: while any doctor might contribute observations, "drawing of empirical laws from such observations was considered a matter of judgment which, according to elite physicians who affected a fashionable adherence to Baconian principles, only came from proper education and long experience" (see Mark Weatherall, "Making Medicine Scientific: Empiricism, Rationality, and Quackery in mid-Victorian Britain," Social History of Medicine 9, no. 2 [1995]: 175-94, 179).

93. Aikin, View, 225-26.

94. We draw here on Heringman's reapplication of "knowledge worker" to nineteenthcentury antiquarian fieldworkers (1-21). For a more conventional definition of the modern "knowledge worker" of the information age, see James W. Cortada, The Rise of the Knowledge Worker (Woburn, 1998), 11-13. Howard's prison reform methods and thermometric standard fit neatly with Cortada's definition of "knowledge work" as coming into 
existence when a new body of knowledge, created by a new "knowledge handling technology," must be collected, organized, and applied.

95. Susan Scott-Parrish exemplifies this trend in attending to the role of "colonial and non-European testifiers and collectors" in the shaping Enlightenment methods and systems of knowledge (American Curiosity: Cultures of Natural History in the Colonial British Atlantic World [Chapel Hill, 2006], 14-15). 